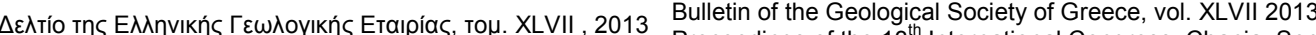
Proceedings of the $13^{\text {th }}$ International Congress, Chania, Sept.

\title{
THE OCCURRENCES OF MG-HYDROXYCARBONATES IN SERPENTINITES OF THE WESTERN SECTION OF THE SOUTH AEGEAN VOLCANIC ARC (WEST ATTICA PENINSULA-NORTHEASTERN ARGOLIS PENINSULA), GREECE
}

\author{
Stamatakis M.G. ${ }^{1}$ and Mitsis I. ${ }^{1}$ \\ ${ }^{1}$ National and Kapodistrian University of Athens, Faculty of Geology and Geoenvironment, \\ Department of Economic Geology and Geochemistry, stamatakis@geol.uoa.gr \\ mitsis@geol.uoa.gr
}

\begin{abstract}
In the area of West Attica Peninsula, Greece, ophiolitic rocks which outcrop mainly at the Geraneia Mountains, overlie Triassic-Jurassic limestone and covered by Plio - Pleistocene sedimentary rocks. The relatively widespread ophiolite occurrences are mainly serpentinized peridotites, considered as spinel lherzolites and dunites. In the Northeastern Argolis Peninsula several small remnants of an ophiolitic nappe outcrop which consists from serpentinized and tectonically deformed peridotites, overthrusted on the Eocene flysch. Both regions are characterized by manifestations of volcanic activity. Recently, white mineral aggregates have been discovered in several places in highly altered and serpentinized ultrabasic rocks of the above regions, with the form of irregular accumulations. The identified minerals are hydromagnesite, which predominates, and also magnesite, huntite, and minerals of pyroaurite group. For the study of the Mg-hydroxycarbonate minerals assemblages and the hosting material, PXRD mineralogical analysis, SEM investigations and SEM-EDS microprobe and chemical analyses has been performed. It is suggested that the origin of the secondary Mg-rich hydroxycarbonates was controlled by the alteration of the ophiolites due to a combining actions of intense hydrothermal activity with $\mathrm{CO}_{2}$-rich fluids, tectonism, as well as the groundwater chemistry that is characterized by high $\mathrm{Mg} / \mathrm{Ca}$ ratio and alkaline $\mathrm{pH}$ values.
\end{abstract}

Key words: Hydromagnesite, huntite, ultramafic, alteration, Geraneia.

\section{Пєрí $\eta \psi \eta$}

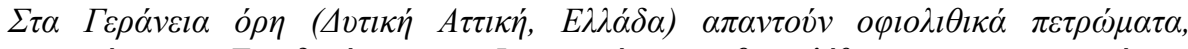

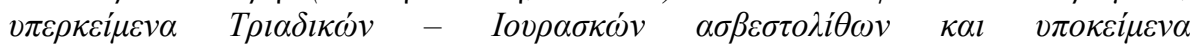

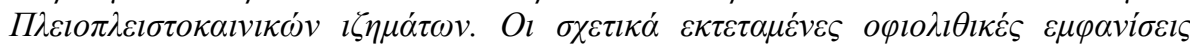

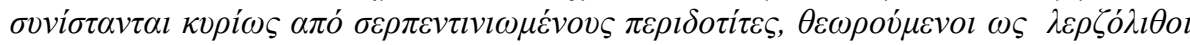

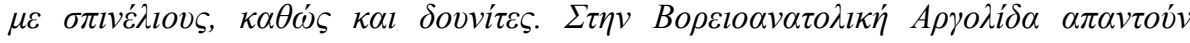

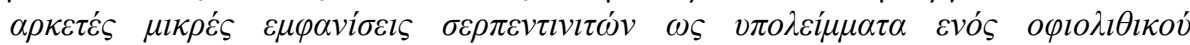

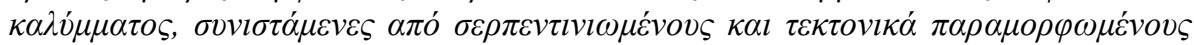

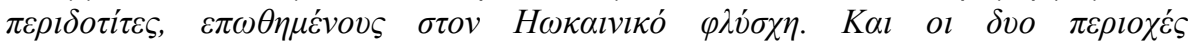




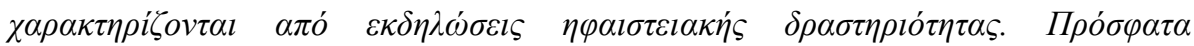

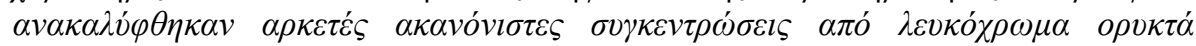

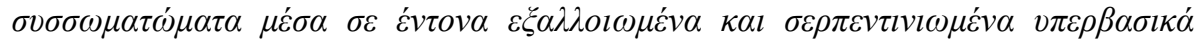

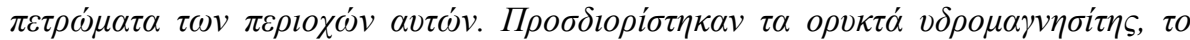

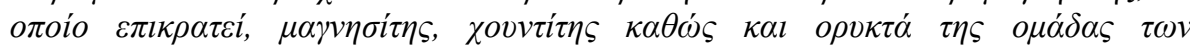

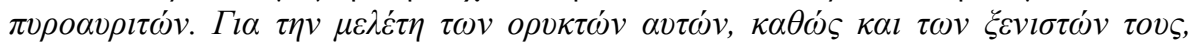

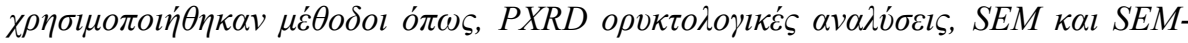

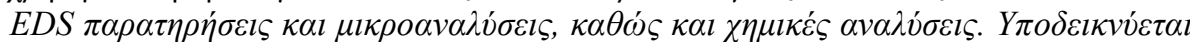

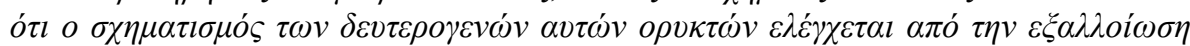

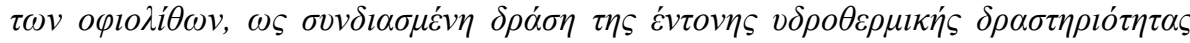

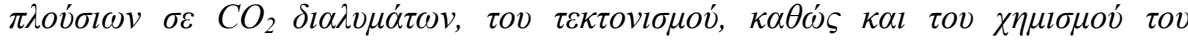

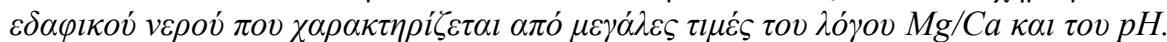

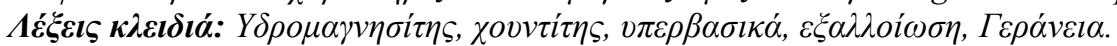

\title{
1. Introduction
}

There are several references for hydromagnesite (and similar minerals, as huntite, pyroaurite group minerals, as well as magnesite, hereinafter referred as Mg-hydroxycarbonates) related with ultramafic rocks (Hostetler et al., 1966, Barnes and O'Neil, 1969, Okamoto et al., 2006, Teir et al., 2009, Wilson et al., 2009). However, these reports, as well as the related occurrences and their extent are very limited on the spread of the ultramafic rocks. The occurrence of Mghydroxycarbonates (such as hydromagnesite and huntite etc) is mainly referred from sedimentary deposits in lacustrine basins of Tertiary to recent age (Calvo et al., 1995, Stamatakis, 1995, Russell et al., 1999, Zedef et al., 2000). However, many of the large magnesite deposits of commercial grade are hosted in ultrabasic rocks in the form of vein and stockwork (Dabitzias, 1980, Pohl, 1990, Zachmann and Johannes, 1989). Sometimes, concretionary magnesites occur in soil weathered ultramafics (Schroll, 2002).

The aim of this paper is the presentation for first time some occurrences of Mg-hydroxycarbonates in ultramafic rocks of Greece, mostly in Geraneia Mountain, as well their description and the mineralogical and geochemical constrains; their relationship with specific geotectonic environment such as the South Aegean Active Volcanic Arc also investigated.

\section{Geologic-Tectonic and Geothermal Features}

In areas in West Attica Peninsula, Greece ( $\mathrm{S}$ in Figure 1), ophiolitic rocks which occur on the surface mainly at the Geraneia Mountains, are overlying Triassic-Jurassic limestone and covered by Plio-Pleistocene sedimentary rocks (Mettos et al., 1982, Vakondios, 1996). The ophiolites are consisting mainly from peridotites were considered as spinel lerzolites -Western Mediterranean type, which include dunite bodies (Vakondios, 1996). The wide South section (Crommyonia) is characterized by the presence of manifestations of volcanic/geothermal activity, which has finally resulted in the alteration of ultramafic rocks mainly in the Soussaki and Agia Marina regions. The alteration observed is represented by extensive silicification of the ultramafic rocks (opal and chalcedony formation), as well as by clays formation (smectite and halloysite), which are often $\mathrm{Cr}$ bearing (Mitsis et al., 2009). The Crommyonia region constituted the NW end of the Aegean volcanic arc, characterized by the existence of geothermal field, as well as intense tectonic and seismic activity. The sparse outcrops of dacitic rocks are the remnants of the volcanic activity 4.0-2.3 Ma, late-Pliocene (Fytikas et al., 1986, Pe-Piper and Hatzipanagiotou, 1997). In places, a weak mineralization of vein-type magnesite was located and also some mineralization of authigenic minerals (mainly sulphates) formed from volcanic emanations has been studied (Kyriakopoulos et al., 1990, D'Alessandro et al., 2009). The peninsula of Methana, located in the Northeastern Argolis ( $\mathrm{M}$ in fiure 1), is mostly formed of volcanic product consisting mainly from basaltic andesites

XLVII. No $1-428$ 
to dacites of Pleistocene age (0.9 Ma to historical time]). In the Northeastern Argolis Peninsula several small remnants of an ophiolitic nappe outcrop which consists from serpentinized and tectonically deformed peridotites, as well as ophiolitic mélange (Gaitanakis and Photiades, 1989, Hatzipanagiotou et al., 1988). The nappe is overthrusted on the Eocene flysch. These ophiolite rocks are generally serpentinized, altered, tectonized and mylonitized. The volcanic system of Soussaki is a recent but, extinct volcano, with the post volcanic activity manifestations restricted now to argillification processes, hydrothermal alteration-mineralization, acid leaching, fumaroles and thermal waters (Dotsika et al., 2009). Gas escape displays typical geothermal gas composition, with $\mathrm{CO}_{2}$ as the main component $(>950 \mathrm{mmol} / \mathrm{mol})$, and $\mathrm{CH}_{4}$ and $\mathrm{H}_{2} \mathrm{~S}$ as minor components (D'Alessandro et al., 2006). However, the volcanic/geothermal system of Methana shows much lower activity, which confirmed by the very low $\mathrm{CO}_{2}$ output (D'Alessandro et al., 2008).

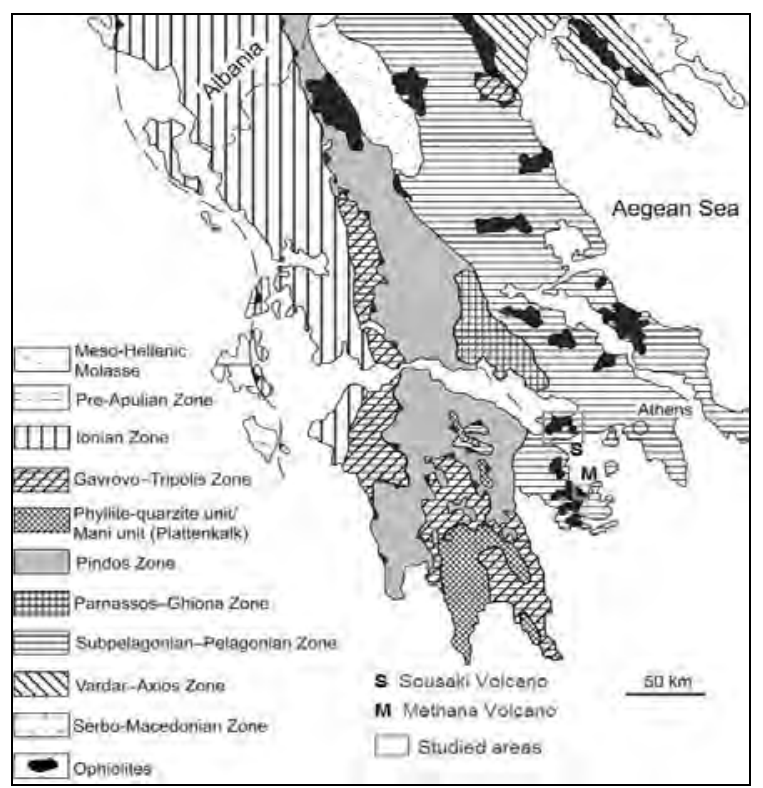

Figure 1 - Simplified geological map with the main tectonostratigraphic zones of the Hellenides and ophiolites also. The studied areas are: S (Sousaki-Geraneia) and M (KaloniMethana).

\section{Materials and Methods}

\subsection{Studied Areas and Sampling}

Recently, in highly altered, often earthy, serpentinite masses, white nodules and cotton-balls, fissure fillings and crusts, as well as veins (Figure 2) composed of Mg-rich hydroxycarbonates were identified mostly in Geraneia Mountain. The main development of the $\mathrm{Mg}$ hydroxycarbonates was found to occur in the highly altered ultrabasic rocks; these rocks occur close to tectonic contact with limestones and close to regions with apparent signs of volcanic/geothermal activity. Away from such areas, the ultramafics are not intensely altered do not contain hydromagnesite, pyroaurite or huntite, but only locally vein-stockwork magnesite. In the South Geraneia Mt (Sousaki area) the ultrabasic rocks are very intensely altered due to volcanic and hydrothermal activity as well as tectonic activity. The Mg-hydroxycarbonate minerals (with the hydromagesite prevails) are well developed and include a variety of forms. Hydromagnesite with the form of cotton balls up to $4 \mathrm{~cm}$ in diameter and as fissure fillings are located in several places within the highly altered serpentinite masses. Magnesite occurs mainly as small layers of white nodular accumulations, crusts or cauliflower forms with colloform texture. Also, boudinaged layers of huntite up to $2 \mathrm{~cm}$ thick as well as nodules up to $2 \mathrm{~cm}$ in diameter occur, 
scattered near surface in totally weathered/altered ultrabasic rocks. The mineralogical analysis has shown that hydromagnesite systematically coexists with pyroaurite (Table 1). In the northern part of Geraneia Mt. (near Schinos area) hydromagnesite cotton balls occur also in totally altered ultrabasic rocks that appears as an earthy, clayey matrix of greenish or yellowish-brown color. The maximum visible thickness of the hydromagnesite horizon development exceeds 10 meters. The hydromagnesite cotton-balls range in size from few $\mathrm{mm}$ up to $5-7 \mathrm{~cm}$ in diameter (Figure 2); the content of irregularly developed hydromagnesite in the host earthy-serpentinite can be close to $30 \%$. In addition, rarely hard magnesite in the form of cauliflower or lettuce-leave assemblages is developed near the present-day surfaces, above hydromagnesite accumulations. In the eastsouthern Geraneia Mt at Ag Theodoroi area white nodular, botryoidal to nephroid and cauliflower accumulations of hard magnesite and rarely disseminated soft huntite nodules have been located in the intensely altered ultrabasic rocks.

In the Northeastern Argolis, at the Kaloni area, near Methana, white nodules, crusts and fissure fillings of hydromagnesite with pyroaurite (Table 1) occurred also in highly altered serpentinite masses. However, these occurrences are clearly quite limited (both in extent and frequency of occurrences) compared with those of Geraneia Mt.

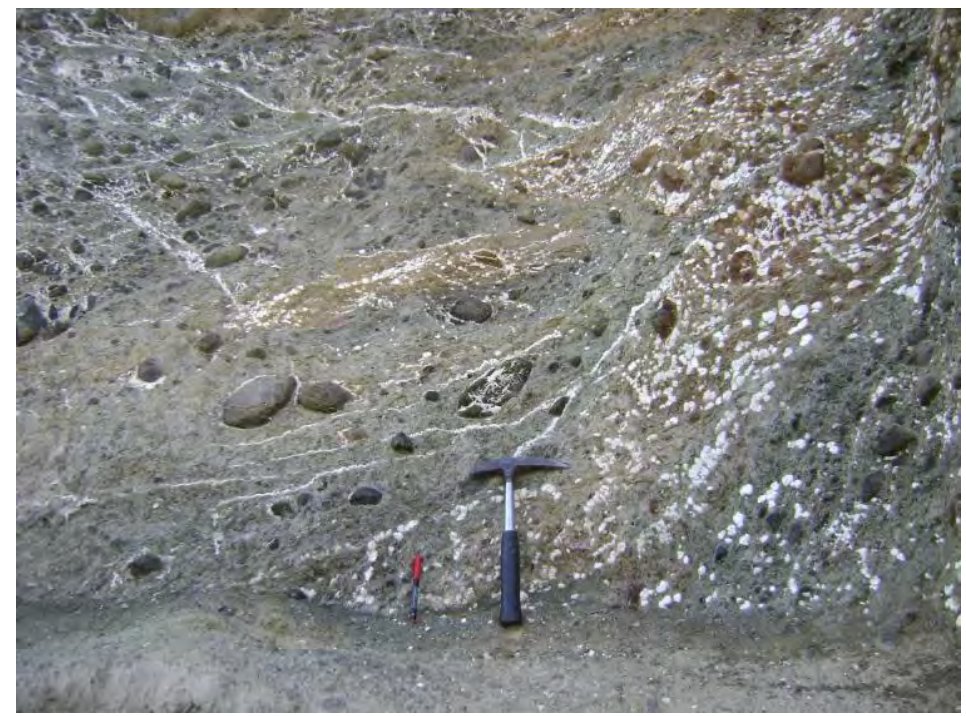

Figure 2 - Hydromagnesite white nodules, fissure fillings and crusts, as well as veins in altered serpentinite in Geraneia Mt.

\subsection{Analytical Methods and Techniques}

All analytical procedures were performed at the laboratories of Faculty of Geology and Geoenvironment, UoA, with the following facilities:

X-ray diffraction measurements were carried out on a Bruker Model 5005 X-ray diffractometer in combination with the DIFFRACplus software package. The diffractometer was operated using $\mathrm{Cu}$ Ka radiation at $40 \mathrm{kV}$ and $40 \mathrm{~mA}$, with graphite monochromator, and employing the following scanning parameters: $0.020^{\circ}$ step size and $1.0 \mathrm{sec}$. step time. The raw files were evaluated for mineralogical identifications by use of the EVA 10.0 program of the Bruker DIFFRACplus- software package. Electron probe microanalyses and SEM studies were carried out on a Scanning Electron Microscopy (SEM) JEOL JSM-5600, combined with microanalyzer energy dispersive system OXFORD LINK ISIS 300, with software ZAF correction quantitative analysis. The system was operating at $20 \mathrm{KV}, 0.5 \mathrm{nA}$ and $50 \mathrm{sec}$ dead time. Wet chemical analyses were performed with AAS spectrophotometer Perkin Elmer, model $1100 \mathrm{~b}$ and with colorimetric method, using a $\mathrm{HACH}$ DR/4000 spectrophotometer. 


\section{Results}

\subsection{XRD Mineralogical Analyses}

As it was resulted from the Powder XRD analyses (Table 1) the major Mg-hydroxycarbonates are: hydromagnesite, pyroaurite, magnesite and huntite. However, several cotton-balls, nodular or crust/fissure filling aggregates revealed that an $\mathrm{Mg}$-Fe-(Ni-rich) hydroxyl-carbonate mineral of the pyroaurite group (Table 1,2) occur, along with hydromagnesite and serpentine mineral.

Table 1 - PXRD Mineralogical analyses.

\begin{tabular}{|c|c|c|c|c|c|}
\hline SAMPLE & SERP & HUN & HYM & MG & PAU \\
\hline AT1 & TR & MD & & MJ & \\
\hline AT2 & & & & MJ & \\
\hline AD2 & TR & & $\mathrm{MJ}$ & & MD \\
\hline $\mathrm{S} 7 \mathrm{a}$ & TR & $\mathrm{MJ}$ & & & \\
\hline S7b & TR & & & MJ & \\
\hline S7c & TR & & MD & MJ & TR \\
\hline S7nd & TR & & $\mathrm{MJ}$ & & $\mathrm{MD}$ \\
\hline $\mathrm{S} 7 \mathrm{v}$ & TR & & & $\mathrm{MJ}$ & \\
\hline AT4 & TR & & $\mathrm{MJ}$ & & MIN \\
\hline AT11 & TR & & $\mathrm{MJ}$ & & MIN \\
\hline AM1 & MJ & & MIN & & MD \\
\hline AMcb & TR & & $\mathrm{MJ}$ & & MD \\
\hline $\mathrm{AMg}$ & TR & & MJ & & MIN \\
\hline AL2 & TR & & $\mathrm{MJ}$ & & MIN \\
\hline AL7 & MD & & MJ & & TR \\
\hline $\mathrm{MPa} 2$ & MD & & TR & & MJ \\
\hline $\mathrm{MPb} 1$ & TR & & MJ & & TR \\
\hline $\mathrm{BPb}$ & TR & & $\mathrm{MD}$ & & MJ \\
\hline $\mathrm{MPb} 2$ & TR & & TR & & MJ \\
\hline $\mathrm{MPb}$ & TR & & & & MJ \\
\hline BPf & MD & & TR & & MJ \\
\hline BPf1 & $\mathrm{MD}$ & & $\mathrm{MJ}$ & & MD \\
\hline $\mathrm{F} 2 \mathrm{~b}$ & TR & & $\mathrm{MJ}$ & & TR \\
\hline F2f & MJ & & $\mathrm{MJ}$ & & MD \\
\hline $\mathrm{PNc}$ & TR & & $\mathrm{MJ}$ & & TR \\
\hline PN5 & TR & & $\mathrm{MJ}$ & & $\mathrm{MD}$ \\
\hline K2a & & & $\mathrm{MJ}$ & & MIN \\
\hline K2 & MIN & & $\mathrm{MJ}$ & & $\mathrm{MD}$ \\
\hline K3 & TR & & $\mathrm{MJ}$ & & MD \\
\hline K20 & TR & & MJ & & MIN \\
\hline
\end{tabular}

Explanatory notes - $\mathrm{SERP}=$ serpentine, $\mathrm{HUN}=$ =huntite, $\mathrm{HYM}=$ hydromagnesite, $\mathrm{MG}=$ magnesite, $\mathrm{PAU}=$ =pyroaurite group $\mathrm{MJ}=$ major constituent, $\mathrm{MD}=$ medium constituent, $\mathrm{MIN}=$ minor constituent, $\mathrm{TR}=$ trace constituent. $(\mathrm{AD}, \mathrm{S})=$ Sousaki area, $(\mathrm{AM}, \mathrm{AL})=\mathrm{Ag}$. Marina area, $(\mathrm{PN}, \mathrm{F})=$ Moni Panagia area, $(\mathrm{AT})=\mathrm{Ag}$. Theodoroi area, $(\mathrm{BP}, \mathrm{MP})=\mathrm{Sxinos}$ area, $(\mathrm{K})=\mathrm{Kaloni}$ area.

\subsection{EPMA Analyses - SEM Micrographs and Study}

SEM study on Mg-hydroxycarbonate phases and varieties of occurrences, shown that all these minerals are authigenic, as forms well developed microcrystals. Hydromagnesite forms euhedral crystals, as well large aggregations with pyroaurite and serpentine (Figure 3 ). 
EPMA analyses, as well SEM semi qualitative analyses on free surface of Mg-carbonate phases and varieties of occurrences shown that: hydromagmesite is a pure phase, pyroaurite contains about $2.0 \% \mathrm{NiO}$ and Magnesite contains about $2.5 \% \mathrm{CaO}$ (Table 2).

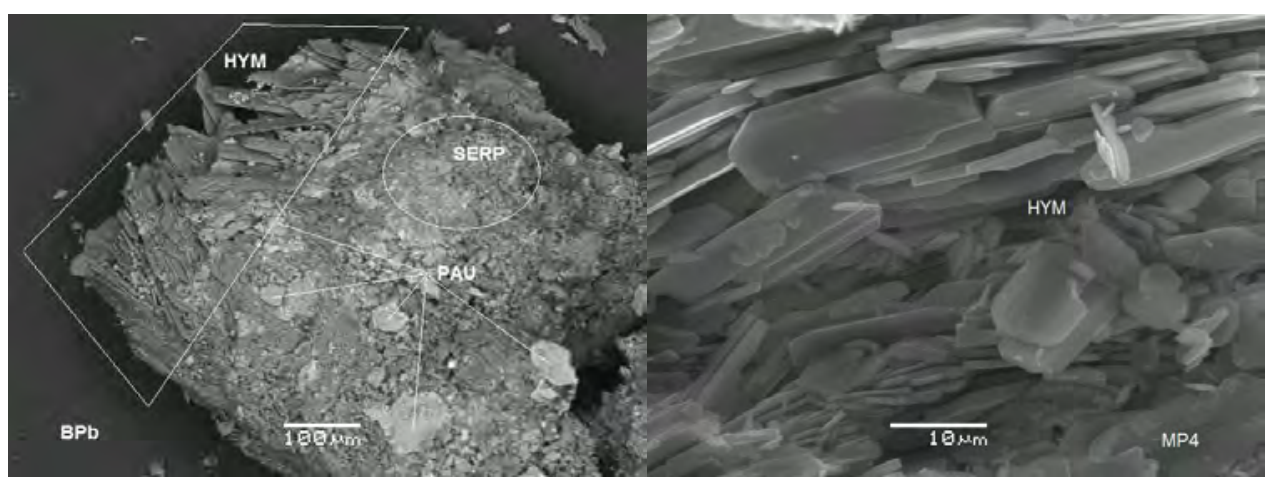

Figure 3 - SEM micrographs of Hydromagnesite (HYM) crystals (euhedral blades), in an aggregation with pyroaurite (PAU) and serpentine (SERP).

Table 2 - EPMA analyses (\%).

\begin{tabular}{|c|c|c|c|c|c|c|c|c|c|c|}
\hline Sample & PN5 & \multicolumn{2}{|c|}{ F2f } & \multicolumn{5}{|c|}{ BPb } & \multicolumn{2}{c|}{ AT2 } \\
\hline Mineral & PAU & HY & HY & PAU & HY & HY & PAU & SER & MG & MG \\
\hline $\mathrm{SiO}_{2}$ & 0.1 & 0.3 & 0.2 & 0.1 & 0.1 & 0.1 & 0.2 & 42.2 & 0.1 & 0.2 \\
\hline $\mathrm{TiO}_{2}$ & bdl & bdl & bdl & bdl & bdl & bdl & bdl & bdl & bdl & bdl \\
\hline $\mathrm{Al}_{2} \mathrm{O}_{3}$ & 0.0 & 0.3 & 0.2 & 0.2 & 0.1 & 0.1 & 0.2 & 0.2 & bdl & bdl \\
\hline $\mathrm{Fe}_{2} \mathrm{O}_{3}$ & 24.8 & 0.1 & 0.1 & 24.2 & 0.1 & 0.1 & 23.9 & 3.7 & 0.1 & 0.1 \\
\hline $\mathrm{MnO}$ & bdl & bdl & bdl & bdl & bdl & bdl & bdl & bdl & 0.1 & 0.2 \\
\hline $\mathrm{MgO}$ & 34.3 & 41.6 & 42.5 & 33.7 & 41.6 & 42.2 & 33.4 & 41.8 & 43.2 & 42.7 \\
\hline $\mathrm{CaO}$ & bdl & bdl & bdl & 0.2 & 0.1 & 0.1 & 0.2 & 0.1 & 2.6 & 2.8 \\
\hline $\mathrm{Na}_{2} \mathrm{O}$ & bdl & bdl & bdl & bdl & bdl & bdl & bdl & bdl & bdl & bdl \\
\hline $\mathrm{K}_{2} \mathrm{O}$ & bdl & bdl & bdl & bdl & bdl & bdl & bdl & bdl & bdl & bdl \\
\hline $\mathrm{Cr}_{2} \mathrm{O}_{3}$ & bdl & bdl & bdl & bdl & bdl & bdl & bdl & 0.2 & bdl & bdl \\
\hline $\mathrm{NiO}$ & 1.9 & bdl & bdl & 2.2 & bdl & bdl & 2.3 & 0.3 & bdl & bdl \\
\hline $\mathrm{Total}^{6}$ & 61.1 & 42.3 & 43.0 & 60.6 & 42.0 & 42.6 & 60.2 & 88.5 & 46.1 & 46.0 \\
\hline
\end{tabular}

Explanatory notes - PAU: Pyroaurite, HYM: Hydromagnesite, SERP: Serpentine, bdl: below detection limits

\subsection{Water Analyses}

The water chemical analyses of all samples analyzed indicate waters of $\mathrm{Mg}-\mathrm{OH}$ type (Table 3). Moreover, the high $\mathrm{pH}$ values, high magnesium and bicarbonates content, low calcium content and therefore high $\mathrm{Mg} / \mathrm{Ca}$ ratio are characteristic of waters emanated from ultrabasic rocks (Papastamataki, 1977).

\section{Discussion - Conclusions}

It has been emphasized the presence of brucite in partially serpentinized dunites or in olivine rich peridotites (Hostetler et al., 1966, Mposkos and Perdikatsis, 1986). It is generally regarded that hydromagnesite and/or pyroaurite formed at the expense of brucite during weathering of ultrabasic rocks. In New Idria serpentinites the content of brucite in the partial serpentinized averages 7-8 per cent and its origin took place during the initial serpentinization of the olivine rich parent. However, it is almost absent from the surface weathering zone (Mumpton and Thompson, 1966). Instead in this zone pyroaurite and hydromagnesite are presented. The latter is localized above the water table often as pea-size concretions. These minerals are considered as alteration products of the brucite: the former in situ, while the hydromagnesite precipitated from ground waters if they 
are in excess (Hostetler et al., 1966, Mumpton and Tompson, 1966). Also, been studied thoroughly the formation of pyroaurite at the expense of brucite during weahtering in dunitic serpentenite in Vourinos, Greece (Mposkos and Perdikatsis, 1986).

Table 3 - Spring waters chemical analyses.

\begin{tabular}{|c|c|c|c|c|c|}
\hline & units & $\begin{array}{l}\text { AL } \\
\text { Wf }\end{array}$ & $\begin{array}{l}\text { MA } \\
\text { Wf }\end{array}$ & $\begin{array}{l}\text { BP } \\
\text { Sp }\end{array}$ & $\begin{array}{l}\text { SN } \\
\text { Fn }\end{array}$ \\
\hline Conductivity & $\mu \mathrm{S} \mathrm{cm}^{-1}$ & 1098 & 1020 & 680 & 680 \\
\hline TDS & $\mathrm{mg} \mathrm{L}^{-1}$ & 605 & 520 & 340 & 341 \\
\hline $\mathrm{pH}$ & & 8.6 & 8.6 & 9.3 & 9 \\
\hline Eh & $\mathrm{mV}$ & -109.8 & -103.3 & -142.1 & -124.1 \\
\hline $\mathrm{T}$ & ${ }^{\circ} \mathrm{C}$ & 21.4 & 20.2 & 19.4 & 20.0 \\
\hline $\mathrm{NO}_{3}{ }^{-}$ & $\mathrm{mg} \mathrm{L}^{-1}$ & 3.5 & 3.5 & 3 & 4.4 \\
\hline $\mathrm{HCO}_{3}^{-}$ & $\mathrm{mg} \mathrm{L}^{-1}$ & 558 & 578 & 354 & 371 \\
\hline $\mathrm{Ca}$ & $\mathrm{mg} \mathrm{L}^{-1}$ & 3 & 2.8 & 0.8 & 1.2 \\
\hline Mg & $\mathrm{mg} \mathrm{L}^{-1}$ & 120 & 154 & 89 & 87 \\
\hline $\mathrm{SO}_{4}{ }^{2-}$ & $\mathrm{mg} \mathrm{L}^{-1}$ & 15 & 15.6 & 2.1 & 0.3 \\
\hline Mg/Ca ratio & & 40 & 55 & 100 & 80 \\
\hline
\end{tabular}

The typical occurrences of hydromagnesite, situated in the areas under investigation, are localized in highly weathered serpentinites. Typical also is the systematic involvement of the pyroaurite group minerals (Table 1, Figure 3); the intimately growth of the hydromagnesite with pyroaurite and serpentine in cotton balls is obvious. The coexistence of the two former minerals in almost all occurrences is remarkable (Table 1,2). Has been suggested that brucite is converted to hydromagnesite if the partial pressure of $\mathrm{CO}_{2}\left(\mathrm{P}_{\mathrm{CO} 2}\right)$ is at least 10-6 atm., whereas probably even smaller $P_{\mathrm{CO} 2}$ values are required for conversion of brucite to pyroaurite group (Hostetler, 1960, Hostetler et al., 1966). The coexistence of hydromagnesite with pyroaurite may indicate intermediate $P_{\mathrm{CO} 2}$ values. However, the predominance of hydromagnesite is also related with the arrangement of the relevant supply of $\mathrm{Mg}$ and $\mathrm{Fe}$ (and $\mathrm{Ni}$ also). Note that the studied hydromagmesite is pure, while pyroaurite contains about $2.0 \% \mathrm{NiO}$ (Table 2). If the concentration of $\mathrm{Mg}$ and the $P_{\mathrm{CO} 2}$ are both high, magnesite forms, whereas low $P_{\mathrm{CO} 2}$ favors the formation of hydromagnesite for a constant $\mathrm{Mg} / \mathrm{Ca}$ ratio (Carpenter, 1962, Stamatakis, 1995). As the $P_{H 2 O}$ approaches the vapor pressure of liquid water brucite or hydromagnesite are stable phases (White, 1997). Besides $\mathrm{Mg}^{2+}$ release from the original $\mathrm{Mg}$-silicate minerals during serpentinization, some $\mathrm{Fe}^{2+}$, as well some $\mathrm{Ni}^{2+}$ is also liberated, and it may be incorporated in precipitated brucite. $\mathrm{Fe}-$ bearing brucite, under small $P_{\mathrm{CO} 2}$ values, is converted to pyroaurite (Hostetler, 1960, Hostetler et al., 1966). In addition, a partial oxidation of the soluble $\mathrm{Fe}^{2+}$ when exposed to mixing zone Eh-pH conditions to $\mathrm{Fe}^{3+}$ in the $\mathrm{Mg}^{2+}$ rich environment at $\mathrm{pH}$ around 8.5 leads to the precipitation of pyroaurite (Hansen and Taylor, 1990, Taylor et al., 1991). Pyroaurite has been formed in a zone beneath the water table and its formation appeared to be restricted to depths near and below the presumed zone of mixing of two different water layers of different composition (Taylor et al., 1991). These are in consistence with two main features of almost all studied occurrences: the weathering and hydrological regimes. The earthy (highly weathered) serpentinite outcrops in the studied areas containing several cotton-balls and veinlets hydromagnesite - pyroaurite occurrences (e.g. near Schinos, Ag. Dimitrios, Kaloni etc) are often wet, due to the present day circulation of surface and ground-water. Obviously, here do not expected to have retained brucite.The secondary Mg-hydroxycarbonates are constantly associated with these "foliated- friable -earthy" serpentinites, usually in areas of tectonic discontinuities and contacts, indicating that the fluid flow was controlled by reactions occurred in these easily accessible masses. Chemical analysis of spring water derived from the altered serpentinite, close to the contact with the limestone has high $\mathrm{pH}$ values, high magnesium and bicarbonates content, low calcium content and therefore high $\mathrm{Mg} / \mathrm{Ca}$ 
ratio (Table 3). The extremely low Eh values also revealed that the spring waters are derived from deep levels and environments isolated from the atmosphere (Garrels and Christ, 1965, Appelo and Postma, 2007). The $\mathrm{Mg} / \mathrm{Ca}$ ratio is ranging between 40 and 100 and it is high enough to start the precipitation of metastable magnesium carbonate minerals such as hydromagnesite and huntite (Stamatakis, 1995, Konigsberger et al., 1999). Brucite formed during initial serpentinization must be regarded as a prime candidate for reaction with $\mathrm{CO}_{2}$ solutions to form magnesite either hydromagnesite either pyroaurite (or coalingite or artinite). In natural environments at surface temperatures hydromagnesite (and/or nesquehonite) can precipitate directly from solutions (Hostleter, 1964); also hydromagnesite (and dipyngite) can precipitate at subsurface directly from solution (Wilson et al., 2009). Magnesite may form by dehydration of hydromagnesite, which forms more rapidly under aqueous conditions (Möller, 1989, Guthrie et al., 2001). The vein type magnesite deposit at Malentrata (Tuscany, Italy) considered as a result of interaction of fluids derived from the active Larderello-Travale high enthalpy geothermal field and the Ligurian serpentinites (Boschi et al., 2009). The serpentinite host rock were hydrothermally completely altered by Siand $\mathrm{CO}_{2}$-rich geothermal fluids to a friable rock consisting mainly of opal, chalcedony, $\mathrm{Al}-\mathrm{Mg}-\mathrm{Cr}$ phyllosilicates and accompanied by the formation of a network of magnesite and dolomite veinlets. These researchers regard that the formation of magnesite may be the result of dehydration of a hydrated precursor (e.g. hydromagnesite). The presence of cauliflower or botryoidal-nodular magnesite with colloform texture at or near surface outcrops above hydromagnesite - pyroaurite occurrences, favoured for such an origin (dehydration of hydromagnesite) of these specific type magnesite aggregates in the studied areas of Geraneia ophiolites. In situ test for $\mathrm{CO}_{2}$ fixation in serpentinite rock mass in the Iwanaidake ultramafic rocks, northern Japan, showed that the groundwater acidified by injected $\mathrm{CO}_{2}$ dissolves brucite and serpentine minerals in the host serpentinite to increase its $\mathrm{Mg}$ content. It is possible that $\mathrm{Mg}$ - hydroxycarbonates precipitate from the highly alkaline groundwater by reaction between $\mathrm{CO}_{2}$ and excess $\mathrm{Mg}$ component; hydromagnesite precipitate in the case of the dunitic serpentinite and pyroaurite or coalingite also formed (Okamoto et al., 2006). Also, serpentinite material from Finland has been acid leaching and then the products magnesium-rich solutions were carbonated by bubbling $\mathrm{CO}_{2}$ and with raising the alkalinity to $\mathrm{pH} 9$, hydromagnesite precipitated (Teir et al., 2009). Most of the required $\mathrm{CO}_{2}$ for the formation of Mg-hydroxycarbonates of the studied areas is more likely to derive from the relevant geothermal system. The $\mathrm{CO}_{2}$ needed for the Mg-hydroxycarbonates formation may derive from meteoric water, but especially in areas of the volcanic manifestations (e.g. gas emanations, fumes and vents in Soussaki area) the geothermal system should virtually be the only source of $\mathrm{CO}_{2}$. Indeed the large amount of $\mathrm{CO}_{2}$ discharged as diffuse and focused in Sousaki area, which estimated for an area of $0.015 \mathrm{Km}^{2}$ and for two small caves to be more than 50 tons/day (D'Alessandro et al., 2006). Obviously it is not necessary volcanic activity for the formation of Mg-hydroxycarbonates, but the high output $\mathrm{CO}_{2}$ in Sousaki volcanic/geothermal area should be correlated with the relatively large and frequent their occurrences. The study of the carbon and oxygen isotopic compositions of the Mg-hydroxycarbonates would help to clarify the source of $\mathrm{CO}_{2}$ as well the conditions of their deposition. The research on this topic is in progress and will be the subject of a forthcoming paper. However, the isotopic composition of carbon and helium of geothermal fluids at Sousaki suggest a prevalent origin from decarbonation reaction of subducted carbonates with only a minor contribution of mantle degassing (D'Alessandro et al., 2005, Dotsika et al., 2009). Obviously the limited occurrences of Mg-hydroxycarbonates at Kaloni area could be correlated with the very low activity of the volcanic/geothermal system of Methana and the very low $\mathrm{CO}_{2}$ output (D'Alessandro et al., 2008).

Therefore, we attribute the relatively widespread Mg-hydroxycarbonate occurrences in Geraneia ophiolites, compared with other regions, in the combination of the following factors:

- The ultrabasic character of Geraneia ophiolites: spinel peridotites whith dunite bodies.

- The active and intense tectonic regime of this region. 
- The great activity of the geothermal fluids and the high $\mathrm{CO}_{2}$ output of Sousaki volcanic/geothermal system.

We conclude that there existed several phases of the evolution of the weathering and the hydrothermal alteration due to geothermal system and tectonic regime of the ultrabasic rocks. Hence, at early periods vein-type magnesite may formed, suggesting that $P_{\mathrm{CO} 2}$ would be was quite high. At later stages, when the $P_{\mathrm{CO} 2}$ and the temperature were lower, as well as the $P_{\mathrm{H} 2 \mathrm{O}}$ approaches the vapor pressure of liquid water, as represents a geothermal system in their waning stage, hydromagnesite and pyroaurite are formed in highly altered, serpentinized masses irregularly developed in the ultrabasic rocks of the studied area. Part of the hydromagnesite then can be dehydrated to the cauliflower or botryoidal-nodular type magnesite with colloform texture, occurred at near surface outcrops, especially near to areas with volcanic/geothermal manifestations. Also, indicated that the Mg-hydroxycarbonate in Argolida may have limited extent due to the very low $\mathrm{CO}_{2}$ output of the Methana volcanic system, in contrast to the case of the region of Sousaki volcano.

\section{Acknowledgments}

Thanks are expressed to the SPECIAL ACCOUNT FOR RESEARCH GRANTS, UoA for funding the fieldwork program under the Project No 70/4/11078. Also, the constructive reviews of two anonymous reviewers improved the text.

\section{References}

Appelo C.A.J. and Postma D. 2007. Geochemistry, groundwater and pollution, A.A. Balkema Publishers, London, 649pp.

Barnes I. and O'Neil J.R. 1969. The relationship between fluids in some fresh Alpine-type ultramafics and possible modern serpentinization, Western U.S., Bull. Geol. Soc. America 80, 1947-1960.

Boschi C., Dini A., Dallai L., Ruggieri G. and Gianelli G. 2009. Enhanced $\mathrm{CO}_{2}$-mineral sequestration by cyclic hydraulic fracturing and Si-rich fluid infiltration into serpentinites at Malentrata (Tuscany, Italy), Chemical Geology 265, 209-226.

Calvo J.P., Stamatakis M.G. and Magganas A. 1995. Clastic huntite in Upper Neogene formations of the Kozani basin, Macedonia, northern Greece, Journal of Sed. Research, A65, 627-632.

Carpenter A.B. 1962. Solutions, minerals and equilibria. Combination diagrams, in Schmitt (ed) Equilibrium diagrams for minerals, Cambridge Mass. Geol. Club of Harvard 1962, 162pp.

D’Alessandro W., Kyriakopoulos K., Rotolo S., Bagnato M., Bruno C., Casa G., Minio M. and Plicanti F. 2005. Natural degassing activity of the geothermal system of Sousaki (Greece): Environmental impact and gas hazard issues, ICGG8, $8^{\text {th }}$ Intern. Conf. Gas Geochemistry, Oct. 2-8, Palermo and Milazzo, Italy, 2005.

D’Alessandro W., Brusca L., Kyriakopoulos K., Rotolo S., Michas G., Minio M. and Papadakis G. 2006. Diffuse and focused carbon dioxide and methane emissions from the Sousaki geothermal system, Greece, Geophysical Research Letters, 33(5) L05307, doi:10.1029/ 2006GL025777, 5pp.

D’Alessandro W., Rotolo S., Kyriakopoulos K., Bellomo S., Brusca L., Calabrese S., Liotta M., Bruno C. and Plicanti F. 2009. Fumarolic alteration products at Sousaki (Greece): occurrence and environmental impact, Proceed. $2^{\text {nd }}$ Int. Conf. CEMEPE\&SECOTOX, Mykonos, June, 21-26 2009.

D’Alessandro W., Brusca L., Kyriakopoulos K., Michas G. and Papadakis G. 2008. Methana, the westernmost active volcanic system of the south Aegean arc (Greece): Insight from fluids geochemistry, Journal of Volcanology and Geothermal Research 178, 818-828.

Dabitzias S.G. 1980. Petrology and genesis of the Vavods cryptocrystalline magnesite deposits, Chalkidiki Peninsula, Northern Greece, Economic Geology, 75, 1138-1151. 
Dotsika E., Poutoukis D., Michelot J.L. and Raco B. 2009. Natural tracers for identifying the origin of the thermal fluids emerging along the Aegean Volcanic arc (Greece): Evidence of Arc-Type Magmatic Water (ATMW) participation, Journ. Volcan. Geotherm. Research $179,19-32$.

Fytikas M., Innocenti F., Kolios N., Manetti P. and Mazzuoli R. 1986. The Plio-Quaternary Volcanism of Saronikos area (Western part of the Active Aegean Volcanic Arc), Ann. Geol. Pays Hell. 33, 23-45.

Gaitanakis P. and Photiades A.D. 1989. The ophiolitic units of Argolis (Peloponnese, Greece), Bull. Geol.Soc. Greece, (in Greece) 23-1, 363-380.

Garels R.M. and Christ C.L. 1965. Solutions, Minerals and Equilibria, Harper and Row (eds), New York, 450pp.

Guthrie G.D., Carey W.J., Bergfeld D., Byler D., Chpera S. and Ziock H.J., 2001. Geochemical aspects of the carbonation of magnesium silicates in aqueous medium, Proceedings of the $1^{\text {st }}$ National Conference on Carbon sequestration p. 14. Washington DC, May 14-17, 2001.

Hansen H.C.B. and Taylor R.M. 1990. Formation of synthetic analogues of double metal-hydroxy carbonate minerals under controlled $\mathrm{pH}$ conditions: I. The synthesis of pyroaurite and reevesite, Clay Miner. 25, 161-179.

Hatzipanagiotou K., Tsikouras V. and Gaitanakis P. 1988. Study of ophiolitic outcrops in Central Argolis: Ophiolitic Melange and residual ophiolitic nappe, Bull. Geol.Soc. Greece, 33, 475492 (in Greece).

Hostetler P. B. 1960. Low temperature relations in the system: $\mathrm{MgO}-\mathrm{SiO}_{2}-\mathrm{CO}_{2} \mathrm{H}_{2} \mathrm{O}$. Ph.D. diss., Harvard Univ., Cambridge, Mass. 168 pp.

Hostetler P.B. 1964. The degree of saturation of magnesium and calcium carbonate minerals in natural waters. General Assembly of Berkeley, Commission of subterranean Waters, Publication No 64, 34-49.

Hostetler P.B., Coleman R.G., Mumpton F.A. and Evans B.W. 1966. Brucite in Alpine serpentinites, The American Mineralogist 51, 75-98.

Konigsberger E., Konigsberger L. and Gamsjager H. 1999. Low temperature thermodynamic model for the system $\mathrm{Na}_{2} \mathrm{CO}_{3} 2 \mathrm{MgCO}_{3} 2 \mathrm{CaCO}_{3} 2 \mathrm{H}_{2} \mathrm{O}$, Geochimica et Cosmochimica Acta $63(19 / 20), 3105-3119$.

Kyriakopoulos K.G., Kanaris-Sotiriou R. and Stamatakis M.G. 1990. The authigenic minerals formed from volcanic emanations at Soussaki, west Attica peninsula, Greece, Canadian Mineralogist 28, 363-368.

Mettos A., Gaitanakis P., Rontogianni Th., Bavay Ph., Ioakim Chr., Mitsaki V. and Koutsouveli A. 1982. Geological Study of "Loutraki-Sousaki” Region, Geothermal Researches, IGME, (in Greek) Greece, 65 (+Apx) pp.

Mitsis I., Godelitsas A., Gottlicher J., Steininger R., Gamaletsos P., Perraki M. and Stamatakis M., 2009. Chromium-bearing Clays from Crommyonia Volcanic Area, Greece, ICC 2009- VIV International Clay Conference, Castellaneta Marina, Italy, June 14-20 2009.

Möller P. 1989. Nucleation processes of magnesite, Monograph series on mineral deposits, 28, 287-292.

Mposkos E. and Perdikatsis V. 1986. Weahtering of Brucite and the formation of Pyroaurite in dunitic serpentenite in the region Xerolivado in the southern Vourjno, (in Greek) IGME Special Issue, 279-287.

Mumpton F.A. and Tompson C.S. 1966. The stability of brucite in the weathering zone of the New Idria serpentinite, Clays and clay Minerals, Proc. Nat. Con No .14, 249-257.

Okamoto I., Yajima T., Mizuochi Y., Katoh T., Ninomiya A. and Ohsumi T., 2006. In-situ test for $\mathrm{CO}_{2}$ fixation in serpentinite rock mass, $8^{\text {th }}$ Int. Conf. on Greenhouse Gas Control Technologies (GHGT-8), Trondheim, Norway June 19-22 2006.

Papastamataki A. 1977. The alkalinity and the chemical composition of springs issuing from peridotites, Anall. Geol des Pays Hellen., 27, 551-566. 
Pe-Piper G. and Hatzipanagiotou K. 1997. The Pliocene volcanic volcanic rocks of Crommyonia, western Greece and their implications for the early evolution of the South Aegean arc, Geol. Mag., 134 (I), 55-66.

Pohl W. 1990. Genesis of magnesite deposits-models and trends, Geologische Rundschau 79-2, 291-299.

Russell M.J., Ingham J.K., Zedef V., Maktav D., Sunar F., Hall A. J. and Fallick A.E. 1999. Search for signs of ancient life on Mars: expectations from hydromagnesite microbialites, Salda Lake, Turkey, Journal of the Geological Society 156, 869-888.

Schroll E. 2002. Genesis of magnesite deposits in the view of isotope geochemistry, Boletim Paranaense de Geociencias, Editora UFPR, IGCP 443, 50, 59-68.

Stamatakis M.G. 1995. Occurrences and genesis of huntite-hydromagnesite assemblages, Kozani, Greece-important new white fillers and extenders, IMM, Transactions-B, 104, 179-186.

Taylor R.M., Hansen H.C.B., Stanger G. and Bender Koch C. 1991. On the genesis and composition of natural pyroaurite, Clay Minerals 26, 297-309.

Teir S., Eloneva S., Fogelholm CJ. and Zevenhoven R. 2009. Fixation of carbon dioxide by producing hydromagnesite from serpentinite, Applied Energy 86, 214-218.

Vakondios J. 1996. Study of the chromite metallogenesis associated with Mediterranean type ophiolites. An example from Tinos Island and Gerania Mt., Attica, Greece, Unpublished Ph.D Thesis, University of patras, Patras, 120pp.

White W. B. 1997. Thermodynamic equilibrium, kinetics, activation barriers and reaction mechanisms for chemical reactions in Karst Terrains, Environmental Geology, 30, 46-58.

Wilson S., Dipple G., Power I., Thom J. anderson R., Raudsepp M., Gabites J. and Southam G. 2009. Carbon Dioxide Fixation within Mine Wastes of Ultramafic-Hosted Ore Deposits: Examples from the Clinton Creek and Cassiar Chrysotile Deposits, Canada, Economic Geology 104, 95-112.

Zachmann D.W. and Johannes W. 1989. Cryptocrystalline magnesite, in Möller (ed), On the formation of magnesite, Monograph Ser. Mineral Deposits, Gebruder Borntraeger, Berlin, 28, $15-28$.

Zedef V., Russel M., Fallik A. and Hall A.J. 2000. Genesis of vein stockwork and sedimentary magnesite and hydromagnesite deposits in the ultramafic terranes of southwestern Turkey: A stable isotope study, Economic Geology 95, 429-446. 